\title{
PERAN KOMUNIKASI PENGURUS FKUB DALAM MENCEGAH KONFLIK ANTAR UMAT BERAGAMA DI KOTA BATAM
}

\author{
THE ROLE OF COMMUNICATION OF FKUB COMMITTEE IN \\ PREVENTING CONFLICTS AMONG BELIEVERS IN BATAM CITY
}

\author{
Nova Dwiyanti \\ (Ilmu Pemerintahan, FISIPOL, Universitas Riau Kepulauan, Batam) \\ novadwiyanti82@gmail.com
}

\begin{abstract}
ABSTRAK
Manusia secara universal (tanpa dipandang suku, etnis, stratifikasi sosial maupun agamanya) merupakan salah satu makhluk Allah yang paling sempurna di muka bumi ini. Allah menciptakan manusia dengan kedudukan yang sama di dunia ini, maraknya isu yang beredar tentang konflik antar umat beragama selama ini menjadi factor penyebab terjadinya beberapa kerusuhan dan kerusakan sesame manusia. FKUB (Forum Kerukunan Umat Beragama) merupakan solusi terbaik dalam mengatasi konflik antarumat beragama. Metode komunikasi yang digunakan pengurus FKUB dalam mengatasi antarumat beragama di kota Batam yaitu melakukan monitoring atau penyuluhan agama ke setiap masyarakat, menjalin kerja sama dengan pemerintah daerah, kepolisian dan pendekatan ormasormas keagamaan yang ada.
\end{abstract}

Kata Kunci: FKUB, umat beragama, monitoring atau penyuluhan agama

\section{ABSTRACT}

Humans universally (regardless of race, ethnicity, social stratification or religion) is one of God's most perfect creatures on earth. Allah created human beings with the same position in this world, the rise of rumors about the conflicts among religious believers has been a factor causing some riots and damage to human beings. FKUB (believers Religious Harmony Forum; Kerukunan Umat Beragama) is the best solution in resolving conflict among religious believers. Communication method used by FKUB committee in handling interfaith in Batam city is by conducting religious monitoring and counseling to each community, cooperating with local government, police and approaching existing religious organizations.

Keywords: FKUB, religious believers, counseling

\section{PENDAHULUAN}

Kerukunan merupakan mencerminkan hubungan timbal balik yang ditandai sikap saling menerima, saling mempercayai, saling menghormati dan saling memaknai kebersamaan. Agama merupakan elemen fundamental dalam kehidupan manusia, oleh karena itu kebebasan umat beragama harus dihargai dan dijamin. Dalam hal ini, negara memberikan kebebasan kepada setiap warga negara menganut agama sesuai pilihannya masing-masing dan menjalankan ibadat 
sesuai kepercayaannya. Hal ini secara jelas dan tegas dicantumkan dalam UUD 1945 pasal 29 ayat (2) yang berbunyi: "Negara menjamin Kemerdekaan tiap-tiap penduduk untuk memeluk agama masing-masing dan untuk beribadat menurut agamanya dan kepercayaannya (Asshideiqie: 2009).

Dalam melaksanakan kewajiban beragama, setiap pemeluk agama hendaknya tidak saling mengganggu, bermusuhan akan tetapi saling hormat menghormati. Untuk menciptakan kerukunan hidup beragama tentunya setiap pengantut mempunyai sifat saling pengertian, bersatu, tolong menolong, damai serta penuh persahabatan antar anggota masyarakat yang hidup bersama. Terealisasinya ketenangan, ketentraman, dan kerukunan umat beragama memiliki arti penting dan manfaat yang besar dalam berbagai bidang kehidupan. Hal ini akan membawa kepada tatanan masyarakat yang hidup rukun penuh persaudaraan, keakraban, rasa kekeluargaan, ramah tamah dan hormat menghormati yang penuh keselarasan. Di samping itu, maka agama agama akan mampu untuk melayani dan menjalankan misi keagamaan dengan baik sehingga terciptanya suasana rukun dalam hidup dan kehidupan masyarakat.

Nilai kerukunan hidup antarumat beragama dipandang dari aspek sosial-budaya menempati posisi yang sangat sentral, penting dan strategis bagi kesatuan dan keharmonisan umat beragama dan sebagai perekat kesatuan melalui ikatan semangat kerukunan hidup antarumat beragama akan mampu membangun atau memperkokoh persatuan masyarakat. Tanpa ikatan semangat kerukunan hidup antarumat beragama, masyarakat pada umumnya akan sangat rentan, rapuh dan hidup dalam suasana yang tidak nyaman karena penuh dengan rasa kecurigaan, ketegangan, dan bahkan akan sering muncul konflik-konflik kekerasan yang berkepanjangan.

\section{PEMBAHASAN}

\section{Bentuk - Bentuk Komunikasi}

Para pakar ilmu komunikasi mengelompokkan pembagian komunikasi dalam bentuk yang bermacam-macam. Mengutip pendapat Mulyana dalam bukunya berjudul Ilmu Komunikasi Sebuah Pengantar bahwasanya membagi bentuk-bentuk komunikasi sebagai berikut:

1. Komunikasi Intrapribadi Komunikasi intrapribadi (intrapersonal communication) adalah komunikasi dengan diri-sendiri. Baik disadari maupun tidak disadari Contoh berfikir. Komunikasi ini merupakan landasan komunikasi antarpribadi dan komunikasi dalam konteks-konteks lainnya, meskipun dalam disiplin komunikasi tidak dibahas secara rinci 
dan tuntas. Dengan kata lain, komunikasi intrapribadi ini inheren dalam komunikasi dua orang,tiga orang, dan seterusnya, karena sebelum berkomunikasi dengan orang lainbiasanya berkomunkasi dengan diri sendiri (mempersepsi dan memastikan makna pesan orang lain), hanya saja caranya tidak disadari. Keberhasilan komunikasi dengan orang lain bergantung pada keefektifan komunikasi dengan diri sendiri (Mulyana: 2007).

2. Komunikasi Interpersonal (antarpribadi)

Secara umum komunikasi interpersonal (komunikasi antarpribadi) dapat diartikan sebagai proses pertukaran makna orang-orang yang saling

berkomunikasi. Komunikasi ini dilakukan oleh dua orang atau lebih dan terjadi kontak langsung dalam bentuk percakapan. Dapat berlangsung dengan

berhadapan muka atau melalui media komunikasi, antara lain dengan

menggunakan pesawat telepon atau radio komunikasi. Komunikasinya bersifat dua arah, yaitu komunikator dan komunikan yang saling bertukar fungsi. Dalam proses komunikasi antarpribadi kemampuan komunikator

diperlukan untuk mengekspresikan diri padaperanan orang lain (empati). Untuk mencapai keberhasilan dalam komunikasi tatap muka perlu didukung dengan penggunaan komunikasi kebahasaan dan bahasa sikap. Ketiga peran bahasa dilaksanakan secara gabungan sehingga muncul keserasian. Contoh penggunaan ketiga peran bahasa tersebut adalah:

a) Komunikasi interpersonal dimulai dengan diri pribadi (self). Berbagai persepsi komunikasi yang menyangkut pengamatan dan pemahaman berangkat dari diri sendiri.

b) Komunikasi interpersonal bersifat transaksional, hal ini mengacu pada tindakan pihakpihak yang berkomunikasi secara serempak mengirim dan menerima pesan.

c) Komunikasi interpersonal, mencangkup isi pesan dan hubungan yang bersifat pribadi (intimacy). Maksudnya, komunikasi interpersonal tidak hanya sekedar berkenaan dengan isi pesan, tapi jugamenyangkut siapa partner kita dalam berkomunikasi.

d) Komunikasi interpersonal mensyaratkan adanya kedekatan fisik antar pihak-pihak yang berkomunikasi.

e) Partisipan dalam komunikasi interpersonal terlibat secara interdependent atau saling bergantung satu dengan lainnya. 
f) Komunikasi tidak dapat diubah atau diulang, jika kita sudah salah mengucapkan sesuatu kepada lawan bicara kita, mungkin kita bisa minta maaf, tetapi tidak berarti menghapus apa yang pernah kita ucapkan (Rakhmat: 1996).

Komunikasi antarpribadi (interpersonal communication) adalah komunikasi antara orangorang secara tatap-muka, yang memungkinkan setiap pesertanya menangkap reaksi yang lain secara langsung, baik secara verbal maupun nonverbal. Bentuk khusus dari komunikasi antarpribadi ini adalah komunikasi diadik (dyadic communication) yang melibatkan hanya dua orang, seperti suami-istri, dua sejawat, dua sahabat dekat, guru-murid, dan sebagainya. Ciri-ciri komunikasi diadik adalah: Pihak-pihak yang berkomunikasi berada dalam jarak yang dekat. Pihak-pihak yang berkomunikasi mengirim dan menerima pesan secara simultan dan spontan, baik secara verbal ataupun nonverbal. Keberhasilan komunikasi menjadi tanggung jawab para peserta komunikasi. Kedekatan hubungan pihak-pihak yang berkomunikasi akan tercermin pada jenis-jenis pesan atau respons nonverbal mereka, seperti sentuhan, tatapan mata yang ekspresif, dan jarak fisik yang sangat dekat. Meskipun setiap orang dalam berkomunikasi antarpribadi bebas mengubah topik pembicaraan, kenyataannya komunikasi antarpribadi bisa saja didominasi oleh satu pihak. Misalnya, komunikasi suami-istri didominasi oleh suami, komunikasi oleh dosen-mahasiswa didominasi oleh dosen, dan komunikasi atasan-bawahan didominasi oleh atasan. Dalam komunikasi biasanya menganggap pendengaran dan penglihatan sebagai indra primer, padahal sentuhan dan penciuman juga sama pentingnya dalam menyampaikan pesanpesan yang bersifat intim. Jelas sekali, bahwa komunikasi antarpribadi sangat potensial untuk mempengaruhi atau membujuk orang lain, karena dapat menggunakan kelima alat indra tadi untuk memepertinggi daya bujuk pesan yang dikomunikasikan kepada komunikan.

\section{Forum Kerukunan Umat Beragama (FKUB)}

Dalam Buku Panduan Pendirian Rumah Ibadat Berdasarkan Keputusan Bersama Menteri Agama dan Menteri Dalam Negeri Nomor 9 dan 8 Tahun 2006 bahwa Forum Kerukunan Umat Beragama yang difasilitasi oleh pemerintah dalam hal ini pemerintah daerah, dalam rangka membangun, memelihara, dan memberdayakan umat beragama dan kesejahteraan mempunyai tugas dan fungsi sebagai berikut:

Pertama, kerukunan umat beragama adalah keadaan-keadaan hubungan sesama umat beragama yang dilandasi toleransi saling pengertian, saling menghormati, menghargai kesetaraan 
dalam pengamalan ajaran agamanya dan kerjasama dalam kehidupan bermasyarakat,berbangsa dan bernegara di dalam Negara Kesatuan Republik Indonesia dan Undang-Undang Dasar1945.

Kedua, pemeliharaan kerukunan umat beragama adalah upaya bersama umat beragama dan pemerintahan di bidang pelayanan, pengaturan dan pemberdayaan umat beragama.

Ketiga, rumah ibadah adalah bangunan yang memiliki ciri-ciri tertentu yang khusus digunakan untuk beribadat bagi para pemeluk masing-masing agama secara permanen, tidak termasuk tempat ibadat keluarga.

Keempat, organisasi KemasyarakatanKeagamaan yang selanjutnya disebut Ormas Keagamaan adalah organisasi non pemerintah bervisi kebangsaan yang dibentuk berdasarkan kesamaan agama oleh warga Negara Republik Indonesia secara sukarela, berbadan hukum, dan telah terdaftar di pemerintahan daerah setempat serta bukan organisasi sayap partai politik.

Kelima, pemuka agama adalah tokoh komunitas umat beragama baik yang memimpin ormas keagamaan maupun yang tidak memimpin ormas keagamaan yang diakui atau dihormati oleh masyarakat setempat sebagai panutan.

Keenam, forum Kerukunan Umat Beragama, yang selanjutnya disingkat FKUB, adalah forum yang dibentuk olehmasyarakat dan fasilitasi oleh pemerintahan dalam rangka membangun, memelihara dan memberdayakan umat beragama untuk kerukunan dan kesejahteraan.

Ketujuh, panitia pembangunan rumah ibadah adalah panitia yang dibentuk oleh umat beragama, ormas keagamaan atau pengurus rumah ibadat.

Delapan, Izin Mendirikan Bangunan (IMB) rumah ibadat adalah izin yang diterbitkan oleh bupati/walikota untuk pembangunan rumah ibadat.

\section{Bentuk Komunikasi Pengurus Forum Kerukunan Umat Beragama dalam Mencegah Konflik Antar Umat Beragama di Kota Batam}

Informasi yang diperoleh dari pengurus FKUB Kota Batam dari hasil wawancara yang dilakukan pada tanggal 21 September 2017 di Kantor Sekretariat FKUB, Berdasarkan informasi yang diperoleh bentuk-bentuk komunikasi yang digunakan pengurus FKUB dalam mengatasikonflik antar umat beragama yaitu: komunikasi antarpribadi, komunikasi massa, komunikasi publik dan komunikasi kelompok.

1. Komunikasi antarpribadi 
Komunikasi antarpribadi menjadikankomunikator dapat memahami lebih banyak informasi tentang suatu permasalahan, baik permasalahan dirisendiri maupun orang lain. Komunikasi antarpribadi pada dasarnya komunikasi antara orang-orang secara tatap muka, yang memungkinkan setiap pesertanya menangkap reaksi orang lain secara langsung, baik secara verbal atau nonverbal. Upaya pengurus FKUB dalam mengatasi konflik antar umat beragama tentunya menciptakan bentuk komunikasi yang efektif salah satunya yaitu komunikasi Intepersonal atau disebut juga komunikasi antarpribadi untuk menciptakan kerukunan umat beragama.

Komunikasi ini disebut komunikasi tatap muka yang dilakukan berulang-ulang dan bergantian untuk meningkatkan mutu komunikasi antarpribadi, dan mampu menjalin suatu kontak dikarenakan ada rangkaian pertukaran pesan antara komunikator dengan komunikan. Komunikasi tatap muka mempunyai keistimewaan dimana efek dan umpan balik, aksi dan reaksi langsung terlihat karena jarak fisik partisipan yang dekat. Aksi maupun reaksi verbal maupun nonverbal, semuanya terlihat dengan jelas dan langsung. Oleh karena itu tatap muka yang dilakukan terus-menerus kemudian dapat mengembangkan komunikasi antarpribadi yang dilakukan sangat yang efektif dan komunikatif. Pengurus FKUB juga melakukan dialog-dialog mengenai situasi dan kondisi terkini terkait kerukunan umat beragamadi Kota Batam, dengan cara mendatangkan, tokoh-tokoh agama, masyarakat dan instansi pemerintah. pengurus FKUB memberikan data hasil dialog atau hasil monitoring pengurus FKUB dan Dewan Penasehat FKUB. Pertama, Untuk menghindari terjadinya kesalahpahaman baik antara sesama muslim dengan antara kelompok nasrani untuk itu tim pengurus dan dewan penasehat Forum Kerukunan Umat Beragama kota Batam melakukan monitoring dan meninjau langsung kelapangan dengan menampung aspirasi dan permasalahan. Kedua, ketika pengurus FKUB dan dewan penasehat langsung turun kelapangan memastikan benar bahwa masalah yang terjadi dapat dengan sigap dapat terselesaikan.

Ketiga, kemudian mengenai informasi adanya dukungan masayarakat muslim di kecamatan sagulung serta Batu aji berdasarkan pengakuan beberapa masyarakat memang ada masyarakatnya yang menandatangai dukungan tersebut namun juga ketidak tahuan atas dan maksud dari surat dukungan tersebut sehingga masyarakat Muslim yang meneken dukungan tersebut akan dicabaut kembali dengan membuat pernyataan lagi. Keempat, monitoring tersebut dilakukan dalam upaya menangkal jangan terjadi gesekan di antaramasayarakat sehingga 
kerukunan umat beragama dapat terjaga dengan baik. Melalui perantara camat, tokoh masyarakat dalam bekerja sama untuk mensosialisasikan peraturan yang telah ditetapkan. Dalam mengatasi konflik antar umat beragama pengurus FKUB sangat membutuhkan dukungan masyarakat agar mengeluarkan aspirasi dan ikut serta membantu program-program FKUB.

\section{Komunikasi massa}

Komunikasi massa yaitu bentuk komunikasi yang menggunakan saluran (Media) dalam menghubungkan komunikator dan komunikan secara massal, berjumblah banyak, heterogen dan menimbulkan efek tertentu. Selain itu pesan yang disampaikan cenderung terbuka dan mencapai khalayak dengan serentak. Komunikasi massa yang dilakukan oleh FKUB Batam dengan menggunakan media cetak. Media cetak yang digunakan diantaranya seperi pemberitaan tentang mematuhi peraturan yang telah ditetapkan selain itu pengurus FKUB menempel spanduk yang di dalamnya berisikan tentang mematuhi peraturan perundang-undangan. pengurus FKUB menggunakan media untuk menyebarluaskan pesan-pesan secara luasdan terus-menerus menciptakan makna-makna serta diharapkan dapat mempengaruhi khalayak agar menciptakan kerukunan umat beragama.

Perkembagan arus informasi harus dimanfaatkan secara baik hal ini tentu saja diterapkan oleh pengurus FKUB dengan maksud supaya masyarakat lebih tertarik lagi dalam mematuhi sikap kerukunan umat beragama dengan melihat peraturan peraturan yang telah ditetapkan. Tentunya media massa merupakan saluran komunikasi yang diperuntukkan untuk menyebarluaskan informasi kepada kahalayak, penyemapaian informasi melalui media massa diharapkan bisa lebih menyeluruh sehingga informasi tersebut bisa di baca untuk dipahami oleh masyarakat. Oleh karenanya pengurus FKUB berusaha menyampaikan nilai-nilai sikap toleransi kepada masyarakat dengan menggunakan media massa, misalnya dengan menggunakan surat kabar lokal. Melihat dari bberapa analisis terkait dengan beberapa bentuk komunikasi massa yang di bentuk pemko batam adalah membuat blog humas Pemerinta Kota Batam yang berisikan setiap umat beragama memiliki pedoman dan kesamaan dalam membangun kerukunan umat beragama.

Perkembangan arus informasi yang canggih saat ini harus dimanfaatkan oleh pengurus FKUB utuk berbagi informasi mengenai peraturan yang telah ditetapkan kepada masyarakat Kota Batm agar tetap menjaga keharmonisan serta sikap kekerabatan dalam diri masyarakat supaya kemajuan dalam kebersamaan bisa dicapai, karena salah satu tolak ukur masyarakat maju 
adalah masyarakat yang terbuka dalam bersikap dan berperilaku. Selain itu FKUB membagikan buku atau brsosur kepada masyarakat dan tokoh-tokoh pemuka agama juga merupakan salah satu bentuk komunikasi yang dilakukan FKUB dalam upaya mensosialisasikan peraturan undangundang yang telah ditetapkan khususnya dalam mensosialisasikan visi dan misi FKUB agar menciptakan keharmonisan beragama dan menjalin sikap toleransi dalam setiap pemeluk agama yang berbeda. Peraturan undang-undang tentang Peraturan Bersama Menteri Agama dan Menteri dalam Negeri No 9 dan 8 Tahun 2006. Maka dengan berbagai peraturan yang telah ditetapkan setiap masyarakat tentunya mengetahui bahwa pentingnya menciptakan kerukunan umat beragama dan menghindari segala bentuk percecokan antara setiap pemeluk agama. Memberikan pemahaman kepada masyarakat mengenai peratutaran yang harus di tegakkan tidak hanya lewat komunikasi massa dan lewat komunikasi publik. Menurut peneliti agar lebih efektif komunikasi antara komunikator dan komunikan perlu jugakomunikasi lewat pengandalian sosial, seperti mendidik agar dalam diri seseorang terdapat perubahan sikap dan tingkah laku agar terbentuknya kerukunan umat beragama.

3. Komunikasi publik atau komunikasi massa

Peran komunikasi pengurus FKUB sangatlah penting dalam mengatasi konflik antarumat beragama. Untuk itu, dalam mensosialisasikan Peraturan Bersama Menteri Agama dan Menteri dalam Negeri Nomor 9 dan 8 Tahun 2006 yaitu melalui pembinaan kepada masyarakat tentang peraturan yang harus diikuti. Untuk menciptakan suasana rukun di kalangan umat beragama, Garis-Garis Besar Haluan Negara (GBHN) memberikan arahan sebagai berikut:

a. Atas dasar keimanan dan ketakwaan bangsa Indonesia terhadap Tuhan Yang Maha Esa, maka kehidupan beragamadan kepercayaan terhadap Tuhan Yang Maha Esa adalah selaras dengan Penghayatan dan Pengamalan Pancasila.

b. Kehidupan beragama dan kepercayaan

terhadap Tuhan Yang Maha Esa makin dikembangkan sehingga terbina kualitas keimanandan ketaqwaan terhadap Tuhan Yang Maha Esa, kualitas kerukunan antar dan antara umat beragama dan penganut kepercayaan terhadap Tuhan Yang Maha Esa dalam usaha memperkukuh persatuan dan kesatuan bangsa serta meningkatkan amal untuk bersama-sama membangun masyarakat. Bertolak dari penjabaran dalam pola dasar Repelita VI sektor Agama, maka kerukunan antar dan antaraumat beragama yang dinamis lebih mantapkan dalam rangka mempekokoh persatuan dan kesatuan bangsa serta menigkatkan amal bersama-sama membangun 
masyarakat, antara lain melalui penyelenggaraan musyawarah intern dan antar pemuka beragama, musyawarah antara pemuka agama dengan pemerintah, dan seminar cendekiawan antarumat beragama.

FKUB Kota Batam seperti layaknya organisasi lainnya tentu memiliki bentuk-bentuk komunikasi yang dapat digunakan untuk mengatasi konflik antarumat beragama. Dalam hal ini pengurus FKUB berperan penting dalam mensosialisasikan dan mewujudkan visi dan misinya yang diterapkan melalui program-program kerja serta kegiatan-kegiatan hal ini bertujuan untuk mewujudkan keharmonisan dalam beragama khususnya untuk mengatasi konflik atau mencegah hal-hal yang tidak diinginkan. Sebagai organisasi yang bergerak dalam kerukunan lintas agama FKUB juga harus terus memberikan informasi, mengedukasi dan mengajak khalayak dalam hal ini seluruh masyarakat untuk meningkatkan keharmonisan dan menjaga kerukunan umat beragama. Pengurus FKUB adalah seperangkat cara yang dilakukan oleh pengurus FKUB untuk menyampaikan pesan dari komunikator kepada komunikan dengan pemperhatikan aspek-aspek penting seperti menyusun pesan, pemilihan komunikator yang mumpuni, pemilihan media dan saluran demi menekan hambatan komunikasi sehingga pesan yang dimaksud dapat tersampaikan dengan baik. Berdasarkan hasil wawancara yang peneliti lakukan dengan pengurus FKUB beliau menjabakan sedikit tentang bentuk-bentuk komunikasi pengurus FKUB dalam mencegah konflik antar umat beragama di Kota Batam FKUB melalui kegiatan-kegiatanya selalu melibatkan tokoh-tokoh tersebut. Salah satu contoh kegiatan rutin setiap tahunnya adalah dialog tokoh pemuda lintas agama, melakukan dialog atau monitoring ke beberapa daerah, dialog tokoh lintas agama dengan PEMKO dan lain sebagainya, yang memungkinkan.

Komunikator yang sangat baik dalam menyampaikann pesan-pesan baik itu pesan pembangunan maupun pesan soal keharmonisan dan lain sebagainya Kriteria komunikator yang baik ada tiga syarat yang harus dipenuhi yaitu, Tingkat kepercayaan orang lain kepada dirinya (kredibilitas), daya tarik dan kekuatan. Pemuka agama memiliki ketiga hal tersebut, sehingga tidaklah sulit jika pemuka agama baik yang tergabung maupun tidakpada organisasi FKUB digunakan sebagai komunikator untuk menyampaikan pesan-pesan terkait dengan kerukunan umat beragama. Ditambah lagi pemuka agama memang memiliki masanya tersendiri yakni para jemaat, jika seluruh pemuka agama dapat menyampaikan pesan-pesan kerukunan kepada jamaatnya, maka bukan tidak mungkin akan semakin banyak orang-orang tersadarkan. Melengkapi kategori ini peneliti juga menanyakan kepada ke tiga informan, selain pemuka 
agama siapa lagi yang mampu menjadi komunikator. Ketiganya menjawab beberapa tokoh seperti pemerintah Kota, tokoh masyarakat dan lain lain yang ikut berperan dalam mewujudkan kedamaian dan keharmonisan dalam umat beragama.

Pada poin selanjutnya akan dijelaskan mengenai strategi pemilihan saluran dan media komunikasi FKUB untuk menyampaikan pesan kepada khalayak. menjawab kategori ini peneliti terlebih dahulu menjelaskan tentang saluran dan media menyangkut dengan penelitian ini. Media dapat dikategorikan dengan beberapa item yakni, Media cetak dan elektronik, Media luar ruang, Media format kecil dan media baru (internet). Sedangkan saluran yakni, Saluran komunikasi kelompok, saluran komunikasi publik dan saluran komunikasi antarpribadi. Dari kategorisasi pemilihan saluran atau media komunikasi, informan lebih banyak memilih saluran komunikasi kelompok berupa dialog, seminar, dan sosialisasi untuk menyampaikan pesan edukatif dan persuasif. Melalui dialog dan seminar tentunyaakan lebih banyak pesan yang mengedukasi dan mengajak para peserta untuk selalu menerapkan dasar-dasar kerukunan umat beragama seperti toleransi dan lain sebagainya. Sedangkan pada penyampaian pesan informatif dan juga persuasif ketiga informan memilih media cetak dan elektronik dan saluran komunikasi publik, yang berisikan pembahasan mengenai isu-isu terkait dengan kerukunan umat beragama khususnya di kota Batam.

Pengurus FKUB memang menitik beratkan pada saluran komunikasi kelompok seperti yang selama ini dilakukan, karena menganggap bahwa dengan begitu dapat menjaring banyak orang walaupun tidak sebanyak apabila dilaksanakan melalui media massa, tetapi saluran komunikasi kelompok menjanjikan lebih banyak peserta yang fokus terhadap hal tersebut dibandingkan khalayak media massa. Selain penyelenggaraan kegiatan dialog, seminar dan sosialisasi yang dilakukan FKUB sendiri, Para anggota yang juga pemuka agama juga membentuk kelompok-kelompok kecil dengan para jemaatnya. Pada kelompok kecil tersebut beberapa jugadapat menjalin saluran komunikasi antarpribadi dengan para jemaatnya. dengan cara seperti ini dapat pula memasukkan konsep -konsep kerukunan umat beragama di tengahtengah masyarakat dalam menghindari konflik antarumat beragama. Dengan demikian saluran dan media yang dipakai pengurus FKUB adalah

Media Cetak dan Elektronik dalam hal ini radio dan surat kabar (seiring dengan kegiatan dialog, seminar dan sosialisasi) dan Saluran Komunikasi Kelompok juga sebagian ada yang memakai saluran komunikasi antarpribadi. Sedangkan penggunaan media luar ruang, media 
format kecil, dan media baru tidak terlalu aktif digunakan dalam rangka penyaluran pesan informative, persuasif dan edukatif (Mustofa: 2006).

\section{KESIMPULAN}

Berdasarkan uraian di atas dapat disimpulkan beberapa hal penting yang menyangkut peran komunikasi yang dilakukan pengurus FKUB Kota Batam dalam mencegah konflik adalah sebagai berikut:

Pertama, Bentuk komunikasi yang digunakan pengurus FKUB dalam mengatasi antarumat beragama di Kota Batam yaitu dapat diklasifikasikan kepada komunikasi antarpribadi, komunikasi publik, dan komunikasi massa. Komunikasi antar pribadi berupa fundrising kepada masyarakat atau para pemuka agama agar menciptakan kerukunan umat beragama. Kemudian komunikasi publik berupa pembinaan kepada masyarakat untuk mengingatkan anggota masyarakat tentang aturan-aturan yang ada yang harus di ikuti, cara menggunakan dan menatati peraturan serta tindakan yang harus dihindari karena bertentangan dengan peraturan dan komunikasi massa yaitu berupa penyebaran brosur-brosur sebagai pemeberitahuaan masalah mentaati Peraturan Bersama Mentri Agama dan Mentri Dalam Negeri Nomor 9 dan 8 Tahun 2006 atau peraturan dan menempelkan spanduk-spanduk di setiap desa maupun tempat-tempat umum.

Kedua, Metode komunikasi yang digunakan pengurus FKUB dalam mengatasi antarumat beragama di Kota Batam yaitu melakukan monitoring atau penyuluhan agama ke setiap masyarakat, menjalin kerja sama dengan Pemerinta Kota, kepolisian dan ormas-ormas keagamaan yang ada di Batam Pendekatan organisasi keagamaan/tokoh agama dan pendekatan pemahaman keagamaan. Untuk menuju kepada perwujudan kerukunan umat beragama yang berkelanjutan tersebut telah ditentukan dengan adanya kerjasama yang harmonis antara sesama pemuka agama, antara pemuka agama dengan aparat pemerintah.

\section{REFERENSI}

, Ali, Mursyid, 2006. Dinamika Kerukunan Hidup Beragama Menurut Perspektif Agama-Agama, Jakarta: Departemen Agama, 
Nova Dwiyanti; Peran Komunikasi Pengurus FKUB Dalam Mencegah Konflik...

Asshideiqie, Jimly, 2009. Komentar Atas Undang-undang Dasar Negara Republik Indonesia Tahun 1945, Jakarta: Sinar Grafika

Buku Panduan Pendirian Rumah Ibadat Berdasarkan Keputusan Bersama Menteri Agama dan Menteri Dalam Negeri Nomor 9 dan 8 Tahun 2006.

Lubis, Ridwan, 2004. BukuPenuntun Kerukunan Hidup Beragama, Medan: LKUP Medan dan Cipta Pustaka Bandung,

Mulyana, Deddy, 2007. Ilmu Komunikasi Suatu Pengantar, Bandung: PT Remaja Rosdakarya

Mustofa, 2006. Kebijaksanaan Pemerintah dalam Pembinaan Kerukunan Hidup Beragama di Indonesia”, Jakarta: Departemen Agama

Rakhmat, Jalaludin, 1996. Psikologi Komunikasi, Bandung: PT Remaja Rosda Karya 